\title{
Hubungan Pengetahuan Perawat tentang COVID-19 dengan Tingkat Stres dalam Merawat Pasien COVID-19
}

\author{
The Relationship between Nurses' Knowledge of COVID-19 and Stress Levels in \\ Treating COVID-19 Patients
}

\author{
Hendro W. Sihombing ${ }^{*}$, Zahra Maulidia Septimar \\ Program Studi Keperawatan STIKes YATSI Tangerang, Banten
}

\author{
*Korespodensi Penulis: \\ Hendro W Sihombing \\ Email: hendrosihombing78@yahoo.com
}

\begin{abstract}
Abstrak
Latar belakang: Pandemi COVID-19 telah menjadi ancaman besar bagi kesehatan masyarakat khususnya perawat. Perawat sebagai garda terdepan rentan mengalami gangguan psikologis seperti stres dan depresi. Tujuan: untuk mengetahui hubungan pengetahuan perawat tentang COVID-19 dengan tingkat stress perawat dalam merawat pasien COVID-19. Metode: Jenis penelitian deskriptif analitik dengan pendekatan cross sectional. Populasi yang digunakan oleh peneliti adalah perawat yang bekerja di Rumah Sakit yang berada di wilayah Provinsi Banten dan DKI Jakarta dengan jumlah sampel sebanyak 396 orang. Pengambilan sampel secara non-probability sampling dengan teknik accidental sampling dengan menggunakan lembar kuesioner analisa secara univariat dan bivariat dengan uji Chi-Square. Hasil penelitian: Mayoritas responden memiliki pengetahuan cukup tentang Covid-19 yaitu 230 (58,1\%) dan mengalami tingkat stres sedang dalam merawatpasien Covid-19 yaitu 245 (61,9\%). Analisis hubungan pengetahuan dengan tingkat stress perawat diperoleh $p$ Value $=0,004$. Kesimpulan: ada hubungan antara pengetahuan perawat dengan tingkat stres dalam merawat pasien Covid-19.
\end{abstract}

Kata Kunci: Covid-19, Pengetahuan Perawat, Tingkat Stres Perawat.

\begin{abstract}
Background: The COVID-19 pandemic has become a major threat to public health, especially nurses. Nurses as front liners are prone to psychological issues such as stress and depression. This study aims to determine the relationship between nurses' knowledge of COVID-19 and their stress level in treating COVID-19 patients. Method: This is an analytical descriptive research with a cross sectional approach. The population used by the author were nurses who worked in hospitals in Banten Province and DKI Jakarta Province with a total sample of 396 people. The sample was collected using non-probability and accidental sampling techniques by using the questionnaires, as well as univariate and bivariate analysis with Chi-Square test. Results: The majority of the respondents, namely 230 (58.1\%) of the respondents had sufficient knowledge of Covid-19, and 245 (61.9\%) of the respondents experienced moderate stress levels in treating Covid-19 patients. The $p$ value obtained from the analysis of the relationship between nurses' knowledge and stress levels was $p$ value $=0.004$. Conclusion: there is a relationship between nurses' knowledge and stress levels in treating Covid-19 patients.
\end{abstract}

Keywords: Covid-19, Nurses' Knowledge, Nurses' Stress Levels 


\section{Pendahuluan}

Epidemi penyakit coronavirus 2019 (COVID-19) adalah keadaan darurat kesehatan publik yang menjadi perhatian internasional dan menimbulkan tantangan bagi ketahanan psikologis. Epidemi global menandakan infeksi corona virus yang sangat cepat sehingga hampir semua negara di dunia terkena wabah COVID19. Meningkatnya jumlah yang terkena virus ini terjadi dalam waktu singkat membutuhkan penanganan yang sangat cepat. Tetapi, sampai saat ini obat spesifik untuk menangani kasus infeksi virus Corona atau COVID-19 belum ditemukan. Saat ini Eropa telah menjadi pusat pandemi virus Corona secara global. Kasus dan kematian akibat COVID-19 lebih banyak di Eropa dibandingkan China. Menurut WHO, saat ini jumlah kasus virus Corona lebih dari 136 ribu yang terjadi sedikitnya di 123 wilayah/Negara. Hampir 81 ribu kasus tersebut ada di wilayah China daratan. Negara Eropa yang terdampak virus Corona terparah adalah Italia, dengan jumlah kasus 15 ribu. ${ }^{(1)}$

Wabah pneumonia yang sedang berlangsung terkait dengan coronavirus novel, yang disebut Coronavirus Sindrom Pernafasan Akut Parah (SARS-CoV-2), dilaporkan di Wuhan, provinsi Hubei, Cina pada Desember
2019. Pada minggu-minggu berikutnya, infeksi tersebar di seluruh China dan negara-negara lain di seluruh dunia. Kesehatan masyarakat Cina, klinis, dan komunitas ilmiah mengambil respon segera untuk memungkinkan pengenalan tepat waktu dari virus baru dan berbagi urutan gen virus ke dunia. WHO mengumumkan wabah ini sebagai darurat kesehatan masyarakat pada tanggal 30 Januari 2020. Pada tanggal 12 Februari 2020, WHO menyebut penyakit yang disebabkan oleh coronavirus novel sebagai Penyakit Coronavirus 2019 (COVID$19)^{(1)}$.

Kasus pertama COVID-19 di Indonesia terjadi pada tanggal 1 maret 2020 dengan 2 pasien dari Depok yang terjangkit virus tersebut karena berinteraksi dengan warga Jepang. Virus tersebut juga dengan cepat menyebar diseluruh daerah Indonesia. Berdasarkan data yang diperoleh dari situs resmi Gugus Tugas Percepatan Penanganan COVID-19 per tanggal 19 April 2020 bahwa penderita terus meningkat menjadi 6.760 kasus dengan rincian 5.423 dalam perawatan $(80,22 \%)$, sembuh $747 \quad(11,05 \%)$, meninggal 590 (8,73\%). Diantara kasus tersebut, sudah ada beberapa petugas kesehatan yang dilaporkan terinfeksi. Sampai saat ini, COVID-19 telah 
menyebar di 34 Provinsi di Indonesia, Provinsi DKI Jakarta, Jawa Barat, Jawa Timur, Sulawesi Selatan, Jawa Tengah, dan Banten merupakan 5 Provinsi dengan jumlah kasus positif COVID-19 terbanyak $^{(2)}$.

Munculnya wabah COVID-19 menghadirkan tantangan kesehatan masyarakat diseluruh dunia. Perawat sebagai salah satu tenaga kesehatan garda terdepan yang terlibat dalam menangani pasien COVID-19 memiliki resiko hidup dalam menjalankan tugasnya dan berisiko mengalami stress. Hal ini bisa disebabkan oleh tuntutan pekerjaan yang tinggi, sumber daya yang rendah, dan ketersediaan alat pelindung diri yang sangat minim. Stres kerja yang besar dan gejala stres fisik yang besar dapat menurunkan kesehatan mental dan kesejahteraan. Menjaga kesehatan mental sangat penting untuk mengontrol penyakit menular ${ }^{(3)}$.

Dalam masa pandemi apapun, sangat mungkin banyak orang yang merasa tertekan dan stress. Bisa saja diakibatkan karna takut meninggal, takut kehilangan pekerjaan, merasa tidak sanggup lagi melindungi orangorang tercinta, merasa bosan, merasa sendiri karena terisolasi. Selain itu, bagi tenaga kesehatan khususnya perawat sebagai garda terdepan, stres bisa bertambah berat selama COVID-19 ini yang disebabkan oleh beban kerja yang semakin meningkat, stigmatisasi kepada perawat yang merawat pasien COVID-19, rasa takut menularkan ke saudara/keluarga dan lingkungan sekitar $^{(4)}$.

Saat ini, studi tentang COVID-19 sebagian besar membahas tentang epidemiologi, penanganan dan kontrol, diagnosis dan perawatan. Masih jarang yang membahas tentang kesehatan mental/psikologis tenaga medis khususnya perawat selama pandemik COVID-19. Oleh karena itu, tujuan penelitian ini adalah untuk mengetahui hubungan pengetahuan perawat tentang COVID-19 dengan tingkat stress perawat dalam merawat pasien COVID-19.

\section{Metode}

Penelitian ini menggunakan rancangan cross sectional survey dengan jumlah populasi penelitian 39.122 responden, besaran sampel dihitung menggunakan rumus Slovin diperoleh jumlah sampel sebanyak 396 responden. Metode yang digunakan adalah accidental sampling. Dengan kriteria inklusi Bekerja di Rumah sakit dan pernah merawat pasien ODP, PDP, dan positif COVID-19. Instrumen penelitian yang digunakan yaitu kuesioner yang dikirim secara online, 
selanjutnya dilakukan uji statistik dengan metode chi-square.

\section{Hasil}

Berdasarkan hasil penelitian karakteristik umur responden yang terbanyak adalah umur 19-28 tahun yaitu sebanyak 205 (51,8\%). Karakteristik jenis kelamin responden yang terbanyak adalah perempuan yaitu sebanyak 265 (66,9\%). Karakteristik pendidikan responden yang terbanyak adalah D-III keperawatan yaitu sebanyak 233 $(58,8 \%)$ dan lama kerja responden yang terbanyak adalah $>5$ tahun yaitu sebanyak 188 (47,5\%) (Tabel 1.)

Tabel 1.Distribusi Frekuensi Karakteristik

\begin{tabular}{|c|c|c|}
\hline \multicolumn{3}{|l|}{ Responden } \\
\hline Variabel & $\mathbf{n}$ & $\%$ \\
\hline \multicolumn{3}{|l|}{ Umur } \\
\hline - $19-28$ & 205 & 51,8 \\
\hline - $29-38$ & 123 & 31,1 \\
\hline - $39-48$ & 59 & 14,9 \\
\hline - $>48$ & 9 & 2,3 \\
\hline \multicolumn{3}{|l|}{ Jenis Kelamin } \\
\hline - Laki - laki & 131 & 33,1 \\
\hline - Perempuan & 265 & 66,9 \\
\hline \multicolumn{3}{|l|}{ Pendidikan } \\
\hline - D-III Keperawatan & 233 & 58,8 \\
\hline - S-1 Keperawatan & 163 & 41,2 \\
\hline \multicolumn{3}{|l|}{ Lama Kerja } \\
\hline - <1 Tahun & 54 & 13,6 \\
\hline - 1-2 Tahun & 80 & 20,2 \\
\hline - 3-4 Tahun & 74 & 18,7 \\
\hline - >5 Tahun & 188 & 47,5 \\
\hline
\end{tabular}

Hasil penelitian menunjukkan bahwa tingkat pengetahuan terbanyak yaitu pengetahuan cukup sebanyak 230 $(58,1 \%)$. Tingkat stres mayoritas responden yaitu tingkat stress sedang sebanyak $245(61,9 \%)$ (Tabel 2 dan Tabel 3).

Tabel 2. Distribusi Frekuensi Pengetahuan

\begin{tabular}{ccc}
\hline Pengetahuan & $\mathbf{n}$ & $\%$ \\
\hline Baik & 155 & 39,1 \\
Cukup & 230 & 58,1 \\
Kurang & 11 & 2,8 \\
\hline
\end{tabular}

Tabel 3. Distribusi Frekuensi Tingkat Stress

\begin{tabular}{ccc}
\hline Tingkat Stress & $\mathbf{n}$ & $\%$ \\
\hline Ringan & 99 & 25,0 \\
Sedang & 245 & 61,9 \\
Berat & 52 & 13,1 \\
\hline
\end{tabular}

Hasil analisis lanjut dengan uji stastistic diperoleh $p$ value $0,004<0,05$ yang artinya ada hubungan yang signifikan antara pengetahuan perawat tentang Covid-19 dengan tingkat stres perawat dalam merawat pasien Covid19 (Tabel 4).

\section{Pembahasan}

Karakteristik umur menunjukkan bahwa sebagian besar responden berusia 19-28 tahun yaitu sebanyak $51,8 \%$. Berdasarkan penelitian yang dilakukan oleh Purwindasari serta Prabowo menunjukkan bahwa faktor umur tidak berhubungan dengan stres kerja. Menurut Anoraga, semakin tua seseorang maka orang tersebut semakin rentan mengalami stres, sedangkan menurut Gunarsa seseorang akan rentan mengalami stres pada usia 21-40 tahun dan pada usia 40-60 tahun ${ }^{(5)}$. 
Tabel 2. Hubungan Pengetahuan Perawat tentang Covid-19 dengan Tingkat Stres Perawat dalam Merawat Pasien Covid-19

\begin{tabular}{|c|c|c|c|c|c|c|c|c|c|}
\hline \multirow[t]{3}{*}{ Pengetahuan } & \multicolumn{9}{|c|}{ Tingkat Stres Perawat } \\
\hline & \multicolumn{2}{|c|}{ Ringan } & \multicolumn{2}{|c|}{ Sedang } & \multicolumn{2}{|c|}{ Berat } & \multicolumn{2}{|c|}{ Total } & \multirow[t]{2}{*}{ p Value } \\
\hline & $\mathrm{n}$ & $\%$ & $\mathrm{n}$ & $\%$ & $\mathrm{n}$ & $\%$ & $\mathrm{n}$ & $\%$ & \\
\hline Baik & 34 & 21,9 & 107 & 69,0 & 14 & 9,0 & 155 & 100 & 0.004 \\
\hline Cukup & 58 & 25,2 & 134 & 58,3 & 38 & 16,5 & 230 & 100 & \\
\hline Kurang & 7 & 63,6 & 4 & 36,4 & 0 & 0,0 & 11 & 100 & \\
\hline Jumlah & 99 & 25,0 & 245 & 61,9 & 52 & 13,1 & 396 & 100 & \\
\hline
\end{tabular}

Berdasarkan hasil penelitian didapatkan bahwa mayoritas responden berjenis kelamin perempuan sebanyak 66,9\%. Hal ini sesuai dengan data proporsi perawat di Indonesia Tahun 2017 dari Persatuan Perawat Nasional Indonesia (PPNI) yang menunjukkan bahwa dari 359.339 orang perawat, 156.326 orang $(71 \%)$ berjenis kelamin perempuan. ${ }^{(6)}$ Berdasarkan penelitian yang dilakukanleh Lusia dan Susy didapatkan bahwa perempuan cenderung mengalami tingkat stres yang lebih tinggi dibandingkan laki-laki yaitu $50,3 \%$ dan $4,9 \%$. Ada perbedaan respon antara laki-laki dan perempuan saat menghadapi konflik. Otak perempuan memiliki kewaspadaan yang negative terhadap adanya konflik dan stres, pada perempuan konflik memicu hormon negatif sehingga memunculkan stres, gelisah, dan rasa takut. Sedangkan laki-laki umumnya menikmati adanya konflik dan persaingan, bahkan menganggap bahwa konflik dapat memberikan dorongan yang positif. Dengan kata lain, ketika perempuan mendapat tekanan, maka umumnya akan lebih mudah mengalami stres. Perempuan dan laki-laki memiliki kemampuan beradaptasi yang sama dalam menghadapi stressor yang ada. Ada hubungan antara jenis kelamin dengan stres seseorang. ${ }^{(7)}$

Hasil penelitian didapat bahwa mayoritas responden memiliki pendidikan D-III Keperawatan yaitu sebanyak $58,8 \%$ dan lama kerja $>5$ Tahun 47,5\%. Berdasarkan penelitian yang dilakukan Lusia dan Susi, tingkat pendidikan tidak berpengaruh terhadap skor stres $(p=0,969)$. Semakin tinggi pendidikan seseorang maka akan semakin banyak pengetahuan yang didapatkan sehingga mereka akan lebih mampu mengatasi stres yang terjadi dalam dirinya dibandingkan dengan mereka yang pendidikannya lebih rendah. Tingkat pengetahuan yang kurang dalam menghadapi masalah ditempat kerja dapat memicu terjadinya stres yang daapt mengakibatkan kinerja yang rendah, komunikasi tidak lancar, kurang inovatif. Berdasarkan penelitian yang dilakukan Lusia dan Susi, tingkat 
pendidikan tidak berpengaruh terhadap skor stres $(p=0,969)$. Sejalan dengan penelitian dari Siboro pada pegawai Lembaga

Pemasyarakatan menunjukkan bahwa tingkat pendidikan tidak berpengaruh pada tingkat stres kerja karena tingkat pendidikan berhubungan dengan peran penting dalam perkembangan individu bukan dengan stres kerja. ${ }^{(8)}$

Hasil penelitian ini menunjukkan bahwa dari 396 responden, yang memiliki pengetahuan cukup tentang Covid-19 yaitu sebanyak $58,1 \%$. Hal ini senada dengan penelitian yang dilakukan oleh Zhang et al, dengan judul penelitian Knowledge, attitude, and practice regarding COVID-19 among healthcare workers in Henan, China. Penelitian ini diperoleh hasil bahwa dari 1357 petugas kesehatan di 10 Rumah sakit 89\% dari mereka mempunyai pengetahuan cukup tentang Covid-19.(9) Pengetahuan adalah prasyarat untuk membangun keyakinan pencegahan, membentuk sikap positif, dan mempromosikan perilaku positif, dan kognisi dan sikap individu terhadap penyakit memengaruhi efektivitas strategi dan perilaku koping mereka sampai batas tertentu, semakin besar pengetahuan petugas kesehatan, semakin yakin mereka bisa mengalahkan virus. Selain itu, petugas kesehatan dengan pengetahuan yang lebih besar tentang COVID- 19 percaya bahwa pengunjung dengan faktor-faktor risiko yang signifikan untuk COVID-19 (misalnya kontak dekat dengan kasus yang dikonfirmasi, perjalanan terakhir ke suatu daerah dengan transmisi komunitas) harusmengungkapkan paparan mereka.

Mayoritas responden mengalami stres sedang yaitu sebanyak 61,9\%. Hasil penelitian ini senada dengan penelitian dilakukan di Singapura menunjukkan bahwa COVID-19 berdampak terhadap pekerja medis dan non medis yang bekerja di rumah sakit, seperti kecemasan, stres, post taumatic stress disorder (PTSD) dan depresi. ${ }^{(10)}$ Sementara studi Huang, dkk di China menunjukkan bahwa perawat mengalami emosi negatif (cemas dan takut). Sebagai garda terdepan dalam penanganan COVID-19, pekerja medis (perawat) menghadapi situasi yang tidak pasti, penuh risiko, dan tertekan sehingga mudah mengalami gangguan psikologis. ${ }^{(11)}$

COVID-19 memberikan dampak signifikan terhadap kondisi mental pekerja medis. Sebenarnya perubahan emosi, seperti khawatir, cemas dan stres merupakan respon biasa ketika menghadapi situasi pandemi. Hal itu 
merupakan bentuk mekanisme pertahanan diri atau tanda bahwa ada ancaman yang kita hadapi. Namun, apabila berlebihan, maka akan menganggu kondisi psikologis individu, seperti mengalami depresi. Menurut analisa peneliti, perawat bisa mengalami stres disebabkan oleh beberapa faktor. Contohnya adalah kontak langsung dengan COVID-19, keterbatasan alat pelindung diri, stigma dari masyarakat, kurangnya pengetahuan tentang COVID-19, penggunaan hazmat saat bekerja mengakibatkan panas saat bekerja, tuntutan kerja yang meningkat secara signifikan, harus mengurus anak setelah merawat pasien COVID-19 dan lain sebagainya. Oleh karena itu perawat perlu mendapatkan dukungan dari pimpinan RS, teman dekat dan keluarga untuk mengurangi stres perawat dalam merawat pasien COVID19.

Hasil analisa antara pengetahuan dengan stress perawat diperoleh nilai $p=0,004(<\alpha, 005)$ maka dapat diartikan bahwa ada hubungan yang signifikan antara pengetahuan perawat tentang Covid-19 dengan tingkat stres dalam merawat pasien Covid-19. Sejalan dengan penelitian Fadli et all terdapat pengaruh pengetahuan $(p=0,025)$ terhadap kecemasan petugas kesehatan dalam upaya penanganan, pencegahan, serta perawatan pasien Covid-19. ${ }^{(12)}$

Semakin tinggi pengetahuan seseorang maka kemungkinan mengalami stres sangat rendah. Namun tidak menutup kemungkinan orang yang memiliki pengetahuan baik juga bisa mengalami stres berat. Hal ini bisa disebabkan oleh berbagai factor, contohnya lingkungan kerja yang kurang menyenangkan.

Pada penelitian ini ada perawat memiliki pengetahuan yang baik namun mengalami stress sedang $69 \%$ dan $9 \%$ stress berat. Hal ini bisa saja dipengaruhi karena tuntutan pekerjaan yang lebih tinggi, termasuk waktu kerja yang lama jumlah pasien yang meningkat dan praktik terbaik yang terus berubah seiring perkembangan informasi tentang Covid-19. ${ }^{(13)}$ Maka dari itu, sangat diperlukan dukungan yang besar dari pemerintah untuk penyediaan alat pelindung diri, pelatihan bagi tenaga kesehatan, serta tambahan tunjangan kesehatan baik diri sendiri maupun keluarga. 
Kesimpulan

Pengetahuan perawat tentang Covid-19 berhubungan dengan tingkat stres perawat dalam merawat pasien Covid-19.

\section{Saran}

Hasil penelitian ini dapat digunakan sebagai bahan perbandingan dan referensi untuk penelitian, dan sebagai bahan pertimbangan untuk lebih memperdalam penelititian selanjutnya dengan menggunakan variabel yang berbeda misalnya: sikap, perilaku, ketidaklengkapan APD, dukungan RS atau keluarga, dan lain sebagainya yang dapat mempengaruhi tingkat stres perawat dalam merawat pasien Covid19.

\section{Ucapan Terima Kasih}

Penulis mengucapkan terimakasih para perawat yang merawat pasien COVID-19 dan kepada semua pihak yang berkonstribusi dalam penelitian ini.

\section{Daftar Pustaka}

1. WHO. Coronavirus Disease 2019 (COVID-19) Situation Report-15 [Internet]. 2020. Available from: https://www.who.int/docs/defaultsource/searo/\%0Aindonesia/covid1 9/.
2. Gugus Tugas Percepatan Penanganan COVID-19. Situasi COVID-19 di Indonesia. 2020.

3. Mo Y, Deng L, Zhang L, Lang Q, Liao C, Wang N, et al. Work stress among Chinese nurses to support Wuhan in fighting against COVID19 epidemic. J Nurs Manag. 2020;

4. Inter-Agency Standing Committee. Catatan Tentang Aspek Kesehatan Jiwa dan Psikososial Wabah Covid-19 Versi 1.0. Who. 2020;

5. Irkhami FL. Faktor Yang Berhubungan Dengan Stres Kerja Pada Penyelam Di PT. X. Indones J Occup Saf Heal. 2015;

6. Kemenkes RI. Kemenkes RI [Internet]. infodatin.pdf. Infodatin Perawat 2017 (Pp. 1-12). Pp. 112. 2017. Available from: http://www.depkes.go.id/resources/ download/pusdatin/infodatin/infodat in\%250\%0AAperawat 2017.pdf

7. Kountul YP, Kolibu FK, Korompis GEC. Hubungan Jenis Kelamin dan Pengaruh Teman Sebaya dengan Tingkat Stres Mahasiswa Fakultas Kesehatan Masyarakat Universitas Sam Ratulangi Manado. Kesmas. 2018;

8. Siboro, TS. Hubungan Kondisi Kerja dan Karakteristik Individual dengan Stress Kerja pada Pegawai Lemabaga Permasyarakatan Kelas 
IIB Lubuk Pakam. Thesis. Sekolah Pascasarjana Universitas Sumatera Utara Medan. 2009;183.

9. Zhang M, Zhou M, Tang F, Wang $Y$, Nie $H$, Zhang $L$, et al. Knowledge, attitude, and practice regarding COVID-19 among healthcare workers in Henan, China. J Hosp Infect. 2020;

10. Tan BYQ, Chew NWS, Lee GKH, Jing $\mathrm{M}$, Goh $\mathrm{Y}$, Yeo LLL, et al. Psychological Impact of the COVID-19 Pandemic on Health Care Workers in Singapore. Ann Intern Med. 2020;173(4):317-20.

11. Agung IM. Memahami Pandemi Covid-19 Dalam Perspektif Psikologi Sosial.PsikobuletinBuletin Ilm Psikol. 2020;
12. Fadli F, Safruddin S, Ahmad AS, Sumbara S, Baharuddin R. Faktor yang Mempengaruhi Kecemasan pada Tenaga Kesehatan Dalam Upaya Pencegahan Covid-19. J Pendidik Keperawatan Indones. 2020;6(1):57-65.

13. Inter Agency Standing Comitee (IASC). Interim guidance: public health and social measures for COVID-19 preparedness and response in low capacity and humanitarian settings - Version 1. Inter - Agency Standing Committee. 2020. 